\title{
FIRST RECORD OF SPOTBASE BURRFISH, CYCLICHTHYS SPILOSTYLUS (ACTINOPTERYGII: TETRAODONTIFORMES: DIODONTIDAE), FROM THE MARINE WATERS OF TURKEY
}

\author{
Deniz ERGUDEN $^{1 *}$, Yusuf Kenan BAYHAN ${ }^{2}$, and Cemal TURAN ${ }^{1}$ \\ ${ }^{1}$ Fisheries Genetics and Ecology Laboratory, Fisheries Faculty, Mustafa Kemal University, \\ Iskenderun, Hatay, Turkey \\ ${ }^{2}$ Kahta Vocational School, Adiyaman University, Kahta, Adiyaman, Turkey
}

Erguden D., Bayhan Y.K., Turan C. 2012. First record of spotbase burrfish, Cyclichthys spilostylus (Actinopterygii: Tetraodontiformes: Diodontidae), from the marine waters of Turkey. Acta Ichthyol. Piscat. 42 (2): 137-140.

\begin{abstract}
A single adult specimen of spotbase burrfish, Cyclichthys spilostylus (Leis et Randall, 1982), was recorded for the first time on 26 December 2011 from the Mersin Bay, north-eastern Mediterranean, Turkey. This is the first record of the spotbase burrfish C. spilostylus from the marine waters of Turkey and third record on the continental shelf in the Mediterranean basin. This is the 61th record of an Indo-Pacific alien fish species present along the marine waters of Turkey.
\end{abstract}

Keywords: first record, spotbase burrfish, Cyclichthys spilostylus, Mediterranean Sea, Turkey

After the opening of the Suez Canal, a migration started from the Red Sea to the Mediterranean and up to date totally 83 Red Sea and the Indo-Pacific origin fish species have penetrated into the Mediterranean Sea (Edelist et al. 2011, Golani et al. 2011, Salameh et al. 2011, Bariche and Heemstra 2012). Up to now, 60 alien fish species originally from the Red Sea and the Indo-Pacific Ocean, have been reported in Turkish marine waters (Turan and Yaglıoglu 2011, Çinar et al. 2011, Bilecenoğlu 2012, Dalyan et al. 2012).

On 26 December 2011, a single specimen of spotbase burrfish, Cyclichthys spilostylus (Leis et Randall, 1982) was captured by a trawler in the vicinity of Mersin Bay, Turkey $\left(36^{\circ} 38^{\prime} 44^{\prime \prime} \mathrm{N}, 34^{\circ} 36^{\prime} 18^{\prime \prime} \mathrm{E}\right)$ at a depth of $71 \mathrm{~m}$ (Fig. 1). This record constitutes the first record of this species in the Mediterranean coast of Turkey. The specimen was deposited at the Faculty of Fisheries, Mustafa Kemal University, Iskenderun-Hatay. With the present report, the number of valid Lessepsian fish migrant species recorded in the Turkish marine waters of Turkey has reached sixty one.

Description of the Turkish specimen: The picture of the captured specimen is given in Fig. 2. The meristic counts and morphometric measurements of the captured single specimen is given in Table 1 and compared with other publication (Leis 1986, Golani et al. 2010). Body inflatable, dorsal anal, and caudal fins rounded, dorsal fin slightly in front of anal fin, pectoral fin wide with vertical margin, pelvic fin absent, mouth large and terminal, body wide and head with three-rooted and four-rooted stout spines fixed in an erect position, no spines on the caudal peduncle.

Colour of the fresh specimen. The spotbase burrfish specimen had dark and brown-grey body, belly white, yel-

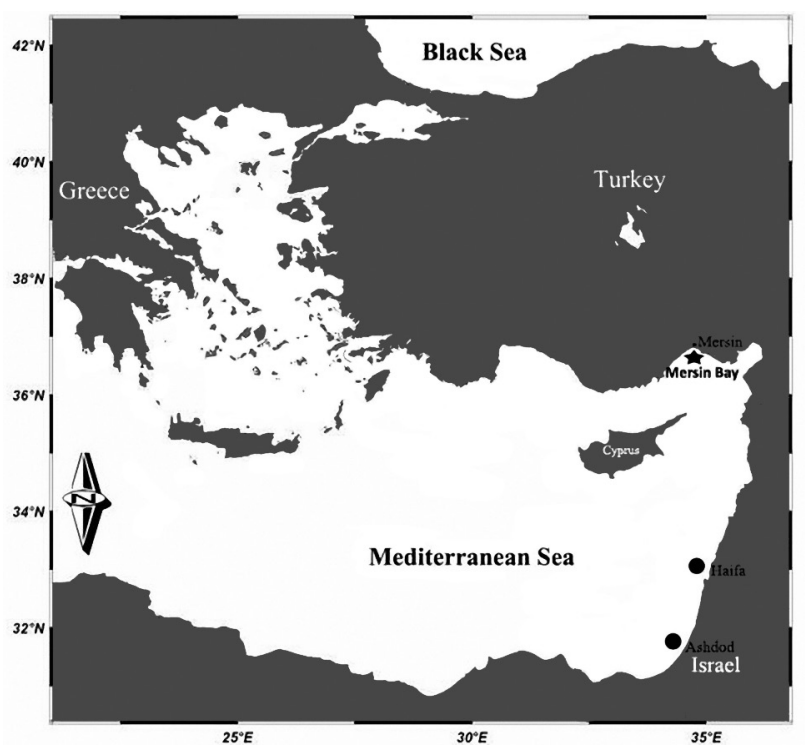

Fig. 1. Map showing records of Cyclichthys spilostylus in the Eastern Mediterranean: •, previous records; $\star$, present record

\footnotetext{
${ }^{*}$ Correspondence: Doc. Dr Deniz Ergüden, Su Ürünleri Fakültesi, Mustafa Kemal Üniversitesi, 31200, Iskenderun, Hatay, Turkey, phone: +(90) 326/6141693-307, e-mail:derguden@yahoo.com (Prof. Dr Cemal Turan’s e-mail: turancemal@yahoo.com).
} 


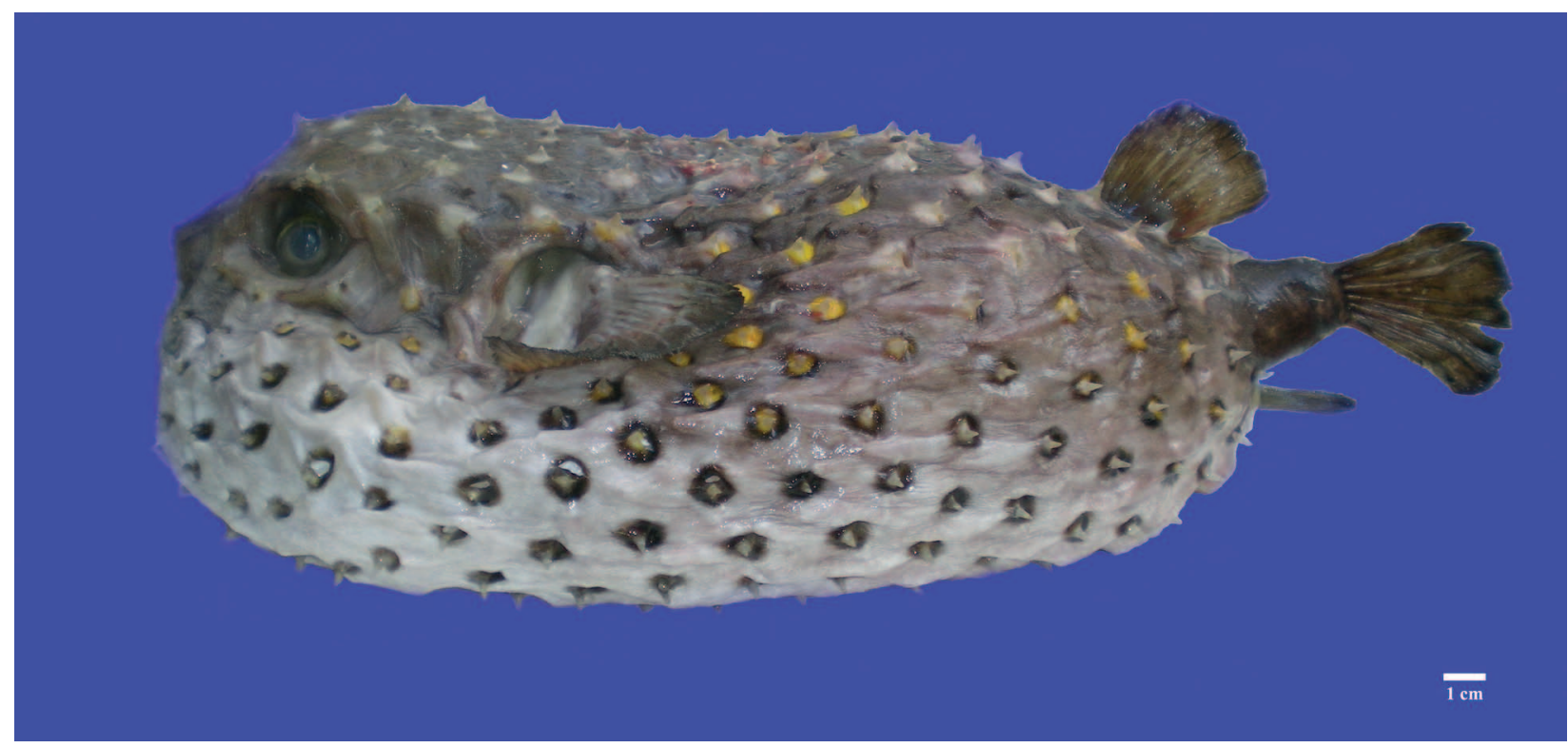

Fig. 2. The specimen of Cyclichthys spilostylus, captured in the Mersin Bay, Turkey; $465 \mathrm{~mm}$ TL (Photo: Y.K. Bayhan)

low-orange spots at the base of spines on the back. Black pinefish, Diodon hystrix L.; spotfin burrfish, spots were present at the base of spines on belly. All Chilomycterus reticulatus (L.); and C. spilostylus (see measurements, meristic counts, morphological descrip- Leis and Randall 1982, Leis 1986, Leis 2001, Follesa et tions, and the colour agreed with the previous descriptions al. 2009). The spotbase burrfish was photographed for the by Leis (1986) and Golani et al. (2010).

Remarks. The family Diodontidae is represented in (Humann 1993) and this species was first described as the Mediterranean Sea by three species: spot-fin porcu- Chilomycterus spilostylus by Leis and Randall (1982)

Table 1

Metric characters and meristic counts of Cyclichthys spilostylus captured in Mersin Bay, Turkey, compared with other Mediterranean records

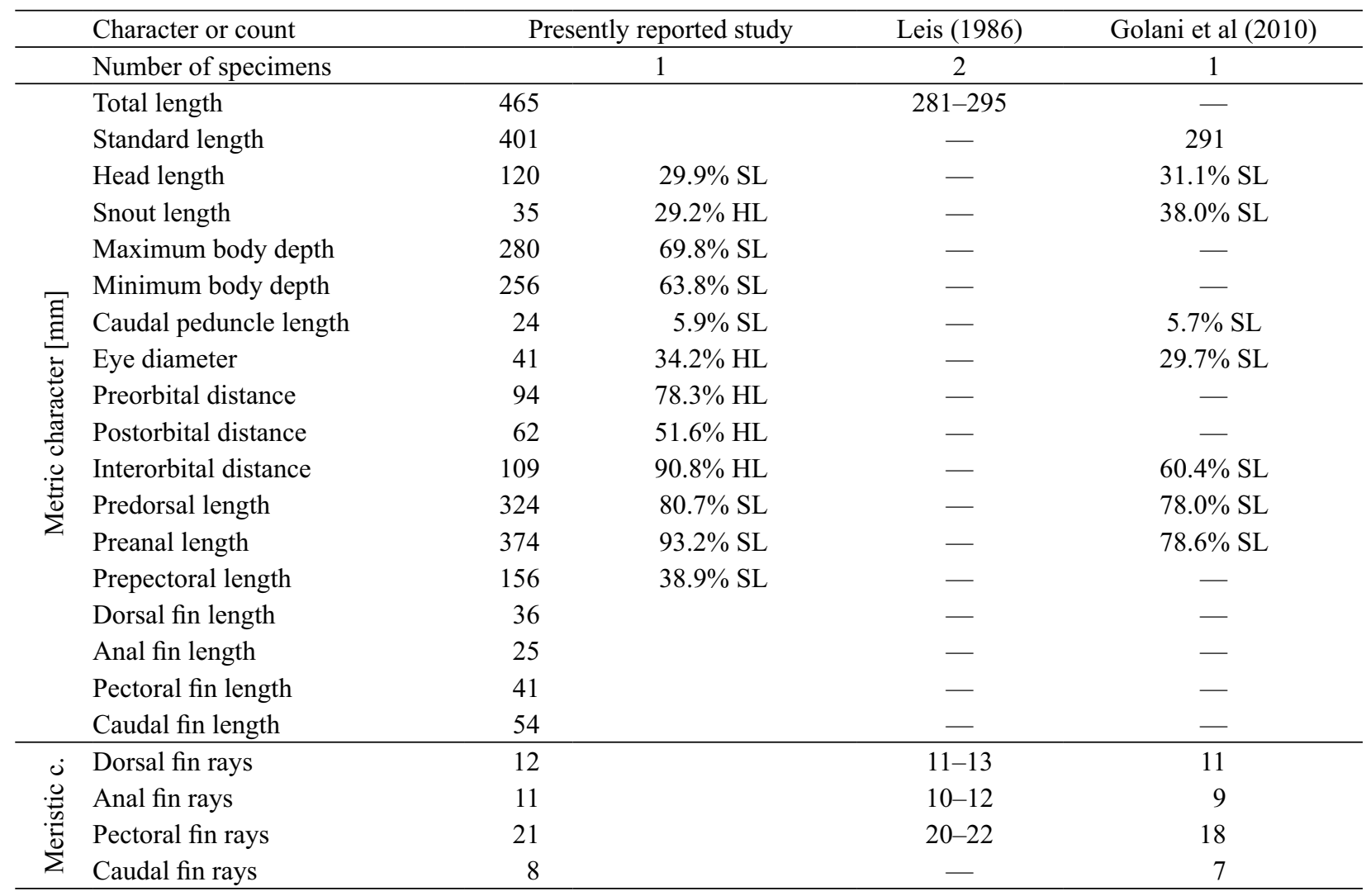


from the Red Sea. Later it was assigned to the genus Cyclichthys (see Matsuura et al. 1993, Leis 2006, Golani et al. 2010). The first Mediterranean record of C. spilostylus was made 1993 from Ashdod, Israel (Golani 1993). About 17 years later, this species was rerecorded again from the Israel waters (Haifa Bay) (Golani et al. 2010).

C. spilostylus lives solitary and can reach up to $350 \mathrm{~mm}$ in total length (Golani et al. 2002). Froese and Pauly (2012) suggested that the maximum total length of this species was $340 \mathrm{~mm}$. Recently, Golani et al. (2010) reported that the standard length was $291 \mathrm{~mm}$ in the Mediterranean (Haifa Bay, Israel). In the presently reported study, the specimen examined was $401 \mathrm{~mm}$ in standard length and $465 \mathrm{~mm}$ in total length. Thus, the presently described C. spilostylus represents the highest documented values of maximum length and weight for this species. In addition, to the best of our knowledge, our specimen's total length is the longest record that has been reported for the entire Mediterranean.

C. spilostylus is distributed along coastal waters in the vicinity of reefs and found on coral or rocky substrate at depths of 3 to $90 \mathrm{~m}$ (Leis and Randall 1982, Froese and Pauly 2012). Although adults are usually found near rocky bottoms, young individuals are known to be pelagic (Froese and Pauly 2012). It feeds on hard-shelled invertebrates (Leis 2001). C. spilostylus is distributed throughout the Red Sea, Indian Ocean, South Africa, South China Sea, Philippines, Japan, Australia, Eastern Pacific, and Mediterranean (Matsuura et al. 1993, Randall 1995, Golani et al. 2010, Froese and Pauly 2012).

The presently reported finding is the first record of C. spilostylus from the marine waters of Turkey and the third record on the continental shelf in the Mediterranean basin. The occurrence of this species in the Mediterranean Sea is most probably due to migration from the Red Sea via the Suez Canal (Golani et al. 2002). While a single specimen does not necessarily indicate existence of an established population in Turkish waters, on the other hand, the past and present records indicate a northward migration of the species with current in the Mediterranean. The sea currents probably help this species to migrate northward. Moreover the lack of records of juvenile specimens of $C$. spilostylus may indicate that it is not spawning in the Mediterranean and, only migrating from the Red Sea via the Suez Canal.

\section{ACKNOWLEDGMENTS}

Thanks to the Ministry of Agriculture and Rural Affairs, General Directorate of Agricultural Research for financial support to the project (TAGEM-09/AR-GE/11) and M. KIRAT for providing the specimen.

\section{REFERENCES}

Bariche M., Heemstra F. 2012. First record of the blacktip grouper Epinephelus fasciatus (Teleostei: Serranidae) in the Mediterranean Sea. Marine Biodiversity Records 5: e1 (3 pages). DOI: $10.1017 / \mathrm{S} 1755267211000509$
Bilecenoğlu M. 2012. First sighting of the Red Sea originated stonefish (Synanceia verrucosa) from Turkey. Journal of Black Sea/Mediterranean Environment 18 (1): 76-82.

Çinar M.E., Bilecenoğlu M., Öztürk B., Katağan T., Yokeş M.B., Aysel V., Dağlı E., Açık S., Özcan T., Erdoğan H. 2011. An updated review of alien species on the coasts of Turkey. Mediterranean Marine Science 12 (2): 257-315.

Dalyan C., Yemişken E., Eryılmaz L. 2012. A new record of gaper (Champsodon capensis Regan, 1908) in the Mediterranean Sea. Journal of Applied Ichthyology DOI: $10.1111 /$ j.1439-0426.2012.02019.x

Edelist D., Spanier E., Golani D. 2011. Evidence for the occurrence of the Indo-Pacific stonefish, Synanceia verrucosa (Actinopterygii: Scorpaeniformes: Synanceiidae), in the Mediterranean Sea. Acta Ichthyologica et Piscatoria 41 (2): 129-131.

DOI: 10.3750/AIP2011.41.2.09

Follesa M.C., Mulas A., Porcu C., Cau A. 2009. First record of Chilomycterus reticulatus (Osteichthyes: Diodontidae) in the Mediterranean Sea. Journal of Fish Biology 74 (7): $1677-1681$.

DOI: $10.1111 / \mathrm{j} .1095-8649.2009 .02229 . \mathrm{x}$

Froese R., Pauly D. (eds.) 2012. FishBase. [version 01/2012] http://www.fishbase.org.

Golani D. 1993. Trophic adaptation of Red Sea fishes to the eastern Mediterranean environment-Review and new data. Israel Journal of Zoology 39 (4): 391-402.

Golani D., Fricke R., Appelbaum-Golani B. 2011. First record of the Indo-Pacific slender ponyfish Equulites elongatus (Günther, 1874) (Perciformes: Leiognathidae) in the Mediterranean. Aquatic Invasions 6 (Suppl. 1): S75-S77. DOI: 10.3391/ai.2011.6.S1.017

Golani D., Orsi-Relini L., Massutí E., Quignard J.P. 2002. CIESM Atlas of E xotic Species in the Mediterranean. Vol. 1. Fishes. CIESM Publishers, Monaco.

Golani D., Salameh P., Sonin O. 2010. First record of the emperor angelfish, Pomacanthus imperator (Teleostei: Pomacanthidae) and the second record of the spotbase burrfish Cyclichthys spilostylus (Teleostei: Diodontidae) in the Mediterranean. Aquatic Invasions 5 (Suppl. 1): S41-S43. DOI: 10.3391/ai.2010.5.S1.010

Humann P. 1993. Reef Fishes Identification. Galápagos. New World Publications, Jacksonville, Florida.

Leis J.M. 1986. Family Diodontidae. Pp. 903-907. In: Smith M.M., Heemstra P.C. (eds.) Smith's sea fishes. McMillian South Africa, Johannesburg.

Leis J.M. 2001. Diodontidae. Porcupine fishes (burrfishes). Pp. 3958-3965. In: Carpenter K.E., Niem V. (eds.) FAO species identification guide for fishery purposes. The living marine resources of the western central Pacific. Vol. 6. Bony fishes. Part 4 (Labridae to Latimeriidae), estuarine crocodiles. FAO, Rome.

Leis J.M. 2006. Nomenclature and distribution of the species of the porcupinefish family Diodontidae (Pisces, Teleostei). Memoirs of Museum Victoria 63 (1): 77-90.

Leis J.M., Randall J.E. 1982. Chilomycterus spilostylus, a new species of Indo-Pacific burrfish (Pisces, Tetraodotiformes, Diodontidae). Records of the Australian Museum 34 (3): 363-371. DOI: $10.3853 /$ j.0067-1975.34.1982.294 
Matsuura K., Sakai K., Yoshino T. 1993. Records of two diodontid fishes, Cyclichthys orbicularis and C. spilostylus, from Japan. Japanese Journal of Ichthyology 40 (3): 372-376.

Randall J.E. 1995. Coastal fishes of Oman. University of Hawaii Press, Honolulu, HI, USA.

Salameh P., Sonin O., Edelist D., Golani D. 2011. First record of the Red Sea orangeface butterflyfish Chaetodon larvatus Cuvier, 1831 in the Mediterranean. Aquatic Invasions 6 (Suppl. 1): S53-S55.

DOI: 10.3391/ai.2011.6.S1.012
Turan C., Yaglıglu D. 2011. First record of the spiny blaasop Tylerius spinosissimus (Regan, 1908) (Tetraodontidae) from the Turkish coasts. Mediterranean Marine Science 12 (1): 247-252.

Received: 9 February 2012 Accepted: 9 May 2012

Published electronically: 30 June 2012 